istry throughout the world. In fact, the sales to nonmembers now greatly exceed in number the membership of the Society itself. Dr. Mitchell became a member of the Society of Public Analysts in 1894 and was co-editor with Dr. Bernard Dyer of the jubilee volume, which gave a most interesting account of the progress of the Society from its foundation in 1875. Dr. Mitchell is well known for his work on oils and fats, on vinegar manufacture, and particularly on the chemistry of writing inks and materials, and is the author of much original work in these fields of applied chemistry. His knowledge and experience in the examination of manuscripts and documents have been of service to the courts on many occasions, and his close association with the forensic world was recognized by his election in 1935 as president of the Medico-Legal Society. $\mathrm{H}_{9}$ is succeeded as editor by Mr. J. H. Lane, who has been assistant editor since 1936.

\section{Australian Council for Scientific and Industrial Research : Retirement of Mr. Gerald Lightfoot}

Mr. Gerald Lightfoot has retired from the post of secretary to the Australian Council for Scientific and Industrial Research. Mr. Lightfoot has been associated with the Council since its inception, and has played an important part both in the building up and in the running of what is now a great and very effective organization. Mr. Lightfoot has had varied experience; he took a first class in the Mathematical Tripos at Cambridge in 1898 and was called to the Bar at Middle Temple in 1902. A few years later he went to Australia and joined the Commonwealth Public Service, and in 1920 was appointed chief executive officer of the Commonwealth Institute of Science and Industry. When this body was reconstituted in 1926 as the Council for Scientific and Industrial Research, he was appointed secretary, and he held this position until his retirement. He reported to the Commonwealth Government on the work and organization of scientific research institutions in Great Britain and the United States, and in 1937 he visited North America, Great Britain and Europe in connexion with an extension of the Council's activities. Much of the information gained on this visit was used in extending the Council's work to the secondary industries and in the setting up of several new divisions before the War.

Those who have been associated with Mr. Lightfoot in his work have high admiration for his sound judgment in dealing with major affairs, for his human understanding and kindness in dealing with people, and for his unfailing attention to detail in handling the numerous minor problems which accompany administration. Fortunately, he remains a member of the Council, which will continue to have the benefit of his advice and experience. He has been succeeded as secretary by Mr. G. A. Cook.

\section{Botanist for India at Kew}

IT has been announced in Science and Culture (India) that Dr. Debabrata Chatterji has been appointed by the Government of India to the post of assistant for India at the Royal Botanic Gardens, Kew. Dr. Chatterji had a brilliant academic career in the Presidency College, Calcutta. After a short period of service as a lecturer in botany at Vidyasagar College, Calcutta, Dr. Chatterji went to the University of Edinburgh in 1937, where he submitted a thesis on "The Endemic Flora of India and Burma" for his doctorate (J. \& Proc. Roy. Asiatic Soc. Bengal); in this connexion he worked at the Royal Botanic Gardens, Kew, and the British Museum. Returning to India in 1939, Dr. Chatterji took up the post of lecturer in botany at the Agricultural College, Mandalay. Owing to progress made by the Japanese, he was forced to leave Mandalay in March 1942, and from April 1942 he served as a systematic botanist in the Botanical Survey, Government of India, for about a year. Since July 1943, he has been a lecturer at Cotton College, Gauhati, Assam. In 1939, Mr. K. N. Kaul of the University of Lucknow was the first Indian appointed an assistant for India at Kew. Mr. Kaul returned to India at the end of 1944 and will now be succeeded by Dr. Chatterji.

\section{Radar During the War}

DURING recent months, much has been published in the daily Press' on various aspects of the many different applications of the new technique known as radiolocation or radar ; and in Nature of September 15, Sir Robert Watson-Watt gave a comprehensive account of the manner in which radar had grown from a classical scientific experiment into a wide series of ramifications developed under the intensive pressure of war. H.M. Stationery Office has now published a pamphlet entitled "Radar-a Report on Science at War" (price 1s. net), which is a reprint of an official report issued by the United States Information Service. After briefly surveying the early history of radar both in Great Britain and in the United States, the pamphlet gives an interesting account in general, non-technical language of the important and very interesting part which radar in its various applications played at different stages of the world war. Although the U.S. Naval Research Laboratory and later the U.S. Army were conducting experiments in the reflexion of radio waves from ships and aircraft from the year 1930 onwards, British radar is credited with having been developed at a faster pace from 1935 under the immediate threat to Britain's security. Before the United States entered the War, however, the efforts of American and British laboratories were combined as the result of an agreement between the two Governments in 1940 and the visit of a British Technical Mission to Washington in September of that year. From that time onwards, the combined efforts of the two nations in research and development, training of personnel, and the operational use of this new weapon at sea, on land and in the air make a fascinating story. The concluding section, on "Radar in the Peacetime World", refers to the effect which the spectacular advances in radio technique made during the war years will have on the future of television and in improving the safety of travel by sea and air. The number of men who have been trained in radio and radar techniques and maintenance is enormous, and many of these will turn their attention to the extended application of electronics in all directions in a manner which is likely to have a profound and farreaching effect on our daily life.

\section{Education in International Morality}

THE inaugural meeting of the United Nations Fellowship was held on September 27, when Prof. R. A. Tsanoff, of the American Army University Centre, Shrivenham, Berks, and professor of philosophy in the Rice Institute, Houston, Texas, opened a discussion on "The Problems of Education in 